This item was submitted to Loughborough's Research Repository by the author.

Items in Figshare are protected by copyright, with all rights reserved, unless otherwise indicated.

\title{
The rise of the non-state 'place-based' economic development strategy
}

PLEASE CITE THE PUBLISHED VERSION

http://dx.doi.org/10.1177/0269094214533650

PUBLISHER

SAGE on behalf of London South Bank University $@$ The Author

VERSION

AM (Accepted Manuscript)

LICENCE

CC BY-NC-ND 4.0

REPOSITORY RECORD

Harrison, John. 2019. "The Rise of the Non-state 'place-based' Economic Development Strategy". figshare. https://hdl.handle.net/2134/14578. 
This item was submitted to Loughborough's Institutional Repository (https://dspace.lboro.ac.uk/) by the author and is made available under the following Creative Commons Licence conditions.

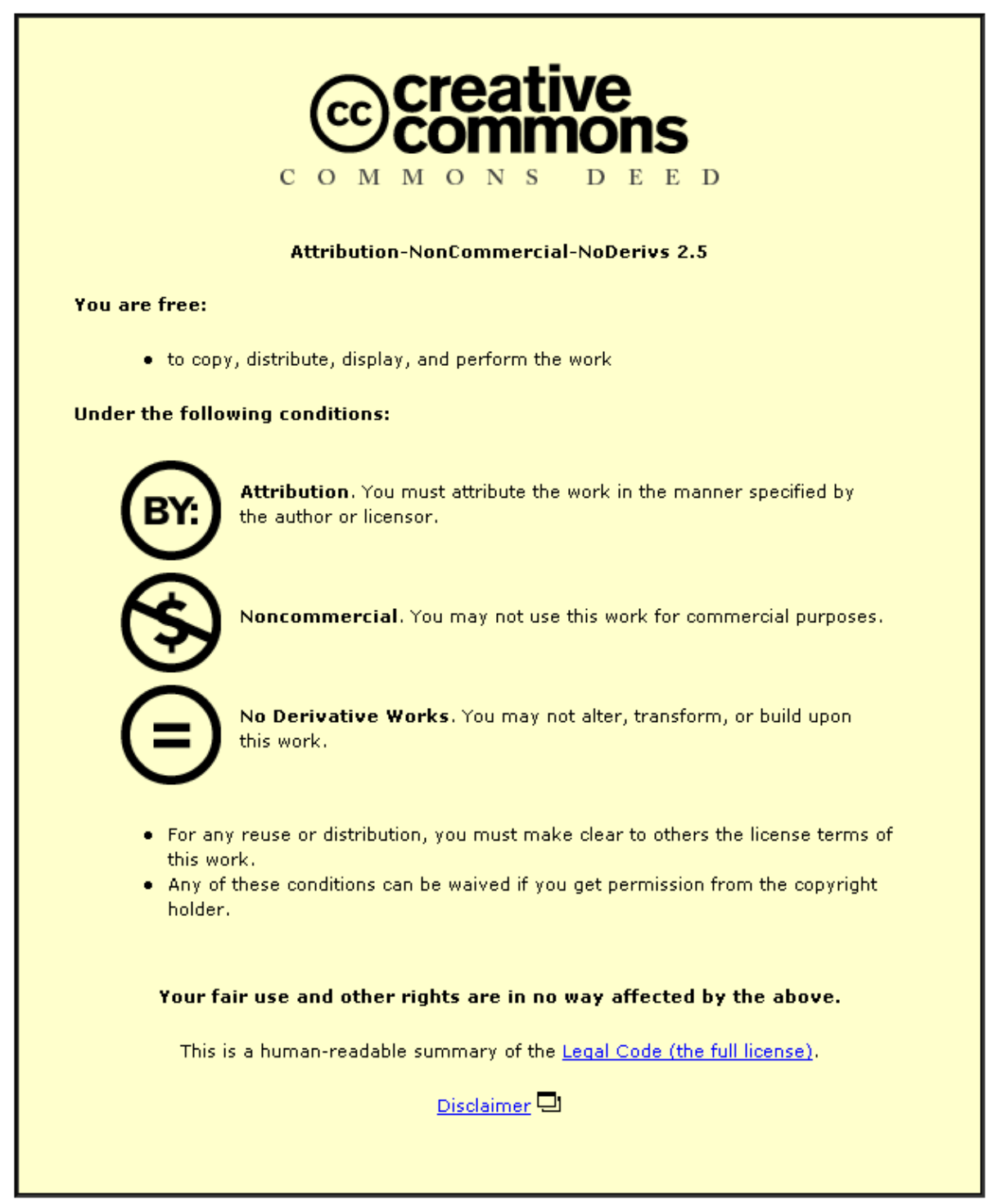

For the full text of this licence, please go to: http://creativecommons.org/licenses/by-nc-nd/2.5/ 


\title{
THE RISE OF THE NON-STATE 'PLACE-BASED' ECONOMIC DEVELOPMENT STRATEGY
}

\author{
John Harrison \\ Department of Geography \\ Martin Hall Building \\ Loughborough University \\ Loughborough, Leics, \\ LE11 3TU \\ $\mathrm{T}:+44(0) 1509228198$ \\ F: $+44(0) 1509223930$ \\ J.Harrison4@lboro.ac.uk
}

Paper submitted for publication in Local Economy 
Abstract This article explores an alternative model of local and regional economic development, specifically the rise of non-state 'place-based' economic development strategies. Illustrated through a case study of the Peel Group's Atlantic Gateway Strategy in North West England, the article showcases the near-future potential for a growth in alternative place-based economic development strategies designed, orchestrated and implemented by non-state actors. In an era where both state and society find themselves increasingly reliant on non-state actors, in particular major private investment groups to deliver the future jobs, growth and regeneration of major urban regions, this article highlights a series of important concerns that the rise of non-state spatial strategies pose for place-based economic development interventions.

Key words Non-state space; spatial strategy; place-based; business-state relations; economic development; Atlantic Gateway 


\section{THE RISE OF THE NON-STATE 'PLACE-BASED' ECONOMIC DEVELOPMENT STRATEGY}

\section{INTRODUCTION: WHAT CHANCE ALTERNATIVE PLACE-BASED ECONOMIC DEVELOPMENT STRATEGIES?}

This article confronts three aspects necessary in (re)appraising contemporary place-based economic development strategies: whether the 2008 financial and ensuing economic crisis can be viewed as a catalyst for fundamentally altering the orientation and implementation of economic development; how on-the-ground economic development strategies are being remodelled in response to the changing institutional landscape for implementing and delivering subnational economic and social policies; and perhaps most significant of all, are there suitable alternative(s to) place-based economic strategies (Pugalis \& Bentley, this issue). The significance of this is not lost, in part, on Lord Heseltine, who when speaking to a UK House of Commons Select Committee inquiry argued:

"If you sit round a table like this, you will find that you have got the chief executives of major companies ... vice-chancellors of universities ... people running the skills councils, and ... people who run the local authorities, either politically or at executive level, and they are the people who are speaking for the local economy on a placebased concept. They are talking about Manchester, Birmingham, Liverpool or wherever it may be. In the present system, if you look to see what sort of people make the decisions today, first of all, there is no place-based mechanism in central Government ... If you think about it in personality terms and in functional and place 
terms, I am arguing that we should create a local dynamic that is a big influence [...] in designing how the local economies benefit from public support money." (Lord Heseltine, quoted in House of Commons Business, Innovation and Skills Select Committee, 2013: Ev 11 emphasis added)

As his evidence attests, the UK Government's current governance model for subnational economic development in England - Local Enterprise Partnerships (LEPs) - is promising, yet ultimately failing, to produce more locally attuned place-based economic development interventions. It should also not be lost on analysts that for Heseltine to argue for a new local dynamic to shape policy intervention is to simply restate the classic devolution demand for more say, more resource, and more autonomy over how localities and regions are governed.

If a step is taken back from this, what can be seen is an attempt to work from within a long-established set of parameters, where decentralisation and devolution are orchestrated by the state, with the state's own interests to the fore. Heseltine's use of the word 'we' in the context of enabling local areas to produce more place-based economic development interventions is particularly significant and should not be overlooked, lest Rodríguez-Pose and Gill's (2003: 334) axiom on devolution be forgotten:

"The complexity of the devolution process derives from the interest conflicts of the actors involved and the differences in legitimacy that they share. ... Although national governments would prefer, ceteris paribus, to devolve responsibilities (authority) to their regional or state governments with as few accompanying 
resources as possible, the subnational governments would prefer the opposite case. The balance between these extremes will depend upon the relative strength, or, in political terms, legitimacy, of the two tiers of government.

The point here is that if the scope for place-based economic development strategies is to be appraised, this devolution conundrum must be recognised in any analysis. Post-Fordist, post-Keynesian, post-national capitalist territorial development can be characterised by periods of systematic governmentalised remappings of state space, with attempts to implement place-based economic development strategies constrained by the parameters of a 'centrally-orchestrated' approach to local and regional economic development; that is, the centre wants something different from the local (cf. Peck, 1995; Harrison, 2008). LEPs are but the latest in this saga.

To explore these issues, the article first offers a critical appraisal of current approaches to place-based economic development strategies. Focusing on the current capabilities of LEPs and the role of private sector engagement in developing and implementing place-based economic development strategies, the second section then makes the case for considering alternatives to the prevailing orthodoxy of neoliberal state spatial restructuring and governmentalised remappings of state space. By this it is meant that there is the need to consider state-centrism and the constraints of the UK's highly centralised system in order to contemplate genuinely alternative place-based economic development strategies. Illustrated through the case study of Peel's Atlantic Gateway Strategy in North West England, in the third section, the article examines of the rise of what may be conceived of as an example of a new non-state place-based economic development strategy. It examines the motivations, tactics and strategies behind Peel's involvement in 
place-based economic development, as well as the mechanisms through which the orientation and implementation of economic development is being remodelled.

The article concludes that on the evidence of what Peel's Atlantic Gateway Strategy signifies, with the private sector taking the lead, this non state place-based strategy might be a valid alternative to state created place-based strategies. It may be that it is private investment, supported by the public sector, which will characterise the next decade of economic development. This increases the potential for more non-state (or certainly private-sector led) spatial strategies to emerge, raising important questions about the shifting relationship between public and private sector. The example of the Atlantic Gateway Strategy shows that while Peel has the money and power to have an increasingly significant say in place-based economic development, it is not a democratic institution and therefore cannot decide what type of place-based economic development is legitimated.

\section{CRITICAL APPRAISAL OF CURRENT APPROACHES TO PLACE-BASED ECONOMIC DEVELOPMENT STRATEGIES}

Although established as the flagship institution for the Cameron-led Government's 'localist' framework in England, LEPs have been constrained from the beginning. A product of the UK state's latest remapping of state space LEPs lack legitimacy, resource, and are not the result of any significant autonomous local action. Lord Heseltine's call for LEPs to be empowered is thus not surprising; this has been seen before in the case of the Regional Development Agencies and Training and Enterprise Councils (Jones, 2013). These institutions had no more power and were no more democratically accountable to localist interests than are the LEPs. The problem is that the parameters which see these institutions created as weak are the same ones which solutions put forward to strengthen them are 
forced to work within. Lord Heseltine's call for LEPs to be empowered with more resource, more power, and more say is a classic example of this. It presupposes LEPs are the answer. But what if LEPs are not the answer, as many critics argue; surely it is necessary to consider the alternatives? Even where LEPs are perceived to be the answer, as advocates would have it, it is necessary to be clear what question they are the answer to.

What this suggests is that the rules of the game continue to be formulated by the central state, with everyone working to those rules. This is no more evident than in Lord Heseltine's opinion that the solution for creating more place-based approach economic development interventions should come from within the state system itself - tasking existing officials from the top-down with new roles and remits (House of Commons BIS Select Committee, 2013). Operating in this way it is tempting to conclude that the power of this state-led approach is precisely that by closing down one alternative to state-led solutions and instituting another, it enables the state to protect its legitimacy in maintaining regulatory control and management of the economy. It is the classic devolution conundrum. This raises the question of whether it is possible to look beyond the confines of a tightlyconstructed state-centred discourse to consider whether genuine alternative(s to) placebased economic development strategies exist.

Whilst there remains undoubted interest and capacity to further develop statecentred analyses, the key point of this article is consideration of the near-future potential for alternative(s to) place-based economic development strategies designed, orchestrated, and implemented by non-state actors. This approach is underscored by three primary considerations. First, institutions of the state are increasingly dependent on non-state actors to deliver the jobs, growth, and regeneration of the future. In part this is due to the crisis of economic development which has seen relative disinvestment in public infrastructure and 
state subsidy (compared with the period of spatial Keynesianism and exacerbated by present day fiscal austerity). Allied to this, there are increasing demands on the state to make greater strategic investments to (1) reduce the public infrastructure deficit in an era when conforming to the discourse of global competitiveness by investing in economic, social and physical infrastructure is deemed essential to creating the localised conditions necessary to tap into trans-national circuits of globalised capital accumulation, and (2) stimulate the economy by bringing forward major infrastructure projects in this era of austerity.

A second point is that there can be little doubt that place (still) matters in this regard. With a predominance of fixed infrastructural investments (e.g. transport networks, energy grids) and public service assets (e.g. schools, hospitals, fire stations) globalising cities have become key regulatory and investment spaces which private industry have set about controlling, managing and extracting value from. Seen from this perspective it might be expected that non-state actors would be taking a more active role in the economic development and regeneration process in these globalising cities; the article contends they are. A third point is that a literature is emerging which identifies the privatisation of urban and regional development and rise of new non-state spatial strategies as emerging trends in local and regional economic development (Knieling et al., 2012; Harrison, 2013). This suggests that is it possible to consider the near-future potential for alternative place-based economic development strategies designed, orchestrated, and implemented by non-state actors; in effect, the takeover of the development of economic strategy and implementation by the private sector. In fact, it may be that non-state actors are better able to deliver placebased economic development strategies? The article turns to explore the issues further in looking at the rise of non-state spatial strategies. 


\section{BEYOND STATE-CENTRISM: EXAMINING THE RISE OF NON-STATE SPATIAL STRATEGIES}

Amid the globalisation of economic and political life much has been made of the trial-anderror search for a new spatial/scalar fix to underpin the post-Fordist growth dynamic. The nature of state spatial strategies and the changes in institutional subnational structures of economic governance have come to reflect the fashionable discourses occupying academics, politicians, and policymakers. The UK (and especially England) is no exception to this; since 1997, the discursive frame has shifted from regions (1997-2004), through cities and regions (2004-2010), to arrive at localism (2010-present). This political praxis has seen the decentralisation of tasks and responsibilities to various subnational institutional frameworks which critics argue has been little more than a 'firework display' (Harrison, 2012). This sees a new initiative launched with a crescendo of noise, sparkle for a short time, only to fizzle out and disappear from sight. The result is a subnational economic development landscape scarred by the 'corpses' of earlier institutions (Bentley and Pugalis, 2013) - a fate likely to be suffered by the LEPs, the latest fashionable institution, and any future decentralised institution that is constructed to this specification (Gash et al., 2014).

\section{Capabilities of LEPs}

Many commentators - both academic and non-academic - see LEPs as an "empty policy" (Jackson et al., 2013, p. 27) which is "destined for oblivion" (Walker, 2012). But while it would be wrong to say that all commentators feel as strongly, given England's affection for perpetual restructuring the question appears not if, but when, LEPs will be abolished (Ward and Hardy, 2013). The problem, as alluded to above, is the rules of the game and the 
contradictions inherent in state-led place-based economic development. Despite being charged with spearheading the Coalition Government's localist approach to economic development, these contradictions include: many of the powers (particularly around business support) being re-centralised in the transition from RDAs to LEPs, ensuring LEPs are less governmentalised than their predecessors; a localist framework where the central state actually determines their priorities and practices (both in the parameters they set when requiring approval of key decisions by Ministers and the conditions/incentives accompanying government funding); LEPs had a brief to operate across functional economic areas yet they have been defined by territorial politics; and where central government's piecemeal approach to furnishing LEPs with resource and power ensured the majority spent their fledgling years fighting for more resources, rather than delivering on economic development objectives.

The LEPs have also been roundly criticised - both as institution and policy initiative for not enabling significant business and community/society involvement in the process. Local accountability or the lack thereof is significant to the Peel case study, particularly given the focus on community-led local development from the European Commission for the 2014-2020 programming period, but business involvement is the main focus here because it is business needs which are driving considerations for conceptualising the 'non-state' placebased strategy.

\section{Private sector engagement}

Evaluating the LEP bids, SQW (2010: 6) argues that business involvement was "in general, thin" and "unsurprising given the difficulty of marshalling the business community to engage in a process that - from their perspective - could have seemed abstract and of no 
immediate consequence". Little improvement appears to have been made over the past two-years. Recent analysis by the Work Foundation suggests the 'clock is ticking' on business involvement, with many business leaders "ready to walk" away if their LEP does not start producing tangible gains in the very near future (Cominetti et al., 2012: 1).

This is a view reinforced by Syrett and Bertotti who, when reconsidering private sector engagement in subnational economic governance, conclude that a limited understanding of private sector engagement means LEPs "provide a fundamentally flawed governance model for addressing the practical realities of pursuing subnational economic development across differentially constituted economic and political urban and regional contexts" (2012: 2312). All three articles point out how the problem is rooted in the terms which the state sets out for private sector engagement in subnational economic development. In short, there is a clear disconnect between the scripted role for business involvement and their actual performance in subnational economic development (Wood, 2004).

This poses searching questions about the prospect for existing place-based economic development strategies to realise socioeconomic goals. But it also prompts consideration of the importance of (re)interpreting business-state relations in the context of subnational economic governance. For identifying the weakness of business involvement is only the first part of the equation. The more substantive part is to identify ways of aligning the interests of business and society within state-led models, or if this is not possible, to seek an alternative model. Syrett and Bertotti (2012: 2313) provide the context for this: 
"Whilst state-centred analyses provide insights into the changing terrain which provides enhanced possibilities for private sector engagement, they have proved largely unable to explore why businesses actually choose to engage (or not) in urban governance, the mechanisms by which actors are engaged, and how the nature of engagement is played out to impact upon the evolution of practice."

With this as a starting point, the authors proceed with an in-depth longitudinal analysis of the implementation of the City Growth Strategy, one of the previous Labour Government's policy initiatives most committed to placing the private sector at the centre of designing and implementing public policy interventions in urban and regional development. A most revealing observation is that:

“despite initial business interest generated by high-profile launch events, it quickly became apparent to the majority of businesses that the City Growth Strategy provided little in the way of immediate business opportunities." (Syrett and Bertotti, 2012: 2318)

This has all the hallmarks of the 'firework' metaphor. Yet it points also towards what is fast becoming a critical body of literature examining the tactics, motives and strategies for business (dis)engagement in subnational economic governance.

At the root of investigations into business-state relations in subnational economic development practices are a series of key questions: What is the motivation for business to get involved in subnational economic governance? How does business involvement unfold in different spatial and temporal contexts? What are the consequences and impacts of 
business involvement on economic development? What tactics and strategies do business leaders use as part of this process ? $^{1}$ Emerging from this critical body of work is a strong sense of divergence in the public and private discourses, approaches, interests, perceptions, strategies and preferences that businesses invoke for their involvement and role in subnational policy. One of the most revealing insights is the move away from earlier explanations, where it was routinely assumed that political engagement was exclusively determined by a strong market rationale that saw businesses only interested in preserving and pursuing material self-interest (see Cox and Mair, 1989), to an appreciation of the wider corporate social and ethical responsibilities, objectives, and motivations of business (Wood, 2004; Syrett and Bertotti, 2012).

This change is certainly evident in analysis of business engagement in LEPs, where material self-interest is seen by almost all business leaders as a 'secondary motivation' given very few report receiving any direct benefit to their business as a result of their involvement with LEPs (Cominetti et al., 2012). A desire to support the local area, alongside networking opportunities, access to information, and prestige, are all seen as more significant motivating factors. Similarly, Syrett and Bertotti (2012) record how, contrary to the scripted role for business in subnational policy, private sector engagement in the City Growth Strategy was predominantly rooted within 'nonmarket' rationales of public service, corporate social responsibility, and urban politics. Yet what is perhaps most revealing is what they deduce from this:

"A model of stripped-down local government with private sector contractors as 'strategic partners' potentially provides business a lead role in local economic development largely unfettered by some of the traditional requirements of 
democratic accountability, transparency, and scrutiny." (Syrett and Bertotti, 2012: 2323)

What is striking about this outcome is the proposed solution remains state-centred. It is about reworking the balance of the current system, a compromise that aims to move the balance slightly more in favour of business vis-a-vis the local state in enacting a lead role in place-based economic development. This is one of many examples, it can be argued, that demonstrate the difficulty in looking beyond the confines of a tightly-constructed statecentred discourse to consider whether genuine alternative(s to) place-based economic development strategies exist. Providing further illustration of the power bound-up within state-led approaches, it is also perhaps why the authors are only prepared to commit to the 'potential' of their proposed solution in assigning business a lead role in place-based economic development? As with many aspirational communiques relating to place-based economic development it appears to be a statement made in hope rather than expectation.

One of the most striking features about work on business-state relations in economic development is how little or no mention is made of businesses themselves. Reference is made to business, not businesses. Names of firms are noticeable only in their absence. The result is a somewhat abstract analysis of how business involvement in UK subnational economic development has evolved post-devolution. Useful in identifying some of the broader trends, themes, and issues, what this approach fails to do is adequately address the specifics of engagement in the economic development process. Missing from the debate are those deep-rooted analyses of actual businesses, particularly those which are actively seeking to take a lead role in subnational economic development. In short, there appears to 
have been little critical thought applied to the firm within current initiatives to engender private-sector led place-based economic development.

\section{Alternatives to the prevailing orthodoxy of neoliberal state spatial restructuring: the case for private sector led 'place-based' economic development}

It goes without saying that firm-centred analyses pose methodological challenges for social science researchers, though these are not insurmountable. ${ }^{2}$ Knieling et al. (2012) for instance have recently provided four examples of specific firms and their strategies to influence spatial development in Germany. Illustrating what they see as the privatisation of urban and regional development, the examples include Siemens in Erlangen, BASF in RhineNeckar, Volkswagen in Wolfsburg, and a consortium of companies led by the Chamber of Commerce and Industry in Cologne to manage the design of the 2008 Cologne Downtown Masterplan. Showcasing examples where firms are taking a lead role in place-based economic development, Knieling et al.'s deeper rooted analysis is noteworthy in the way it not only narrates the individual motivations for the engagement of each firm, but the manner in which it reveals non-state actors becoming increasingly active on the city-wide or city-regional level, and in policy spheres which do not always map onto the corporate interests of the business. As they observe:

"the engagement of private sector actors in the design of public spaces is nothing new, however, they seem to be making strategic decisions not only related to their own business segment. Rather, they have a much larger area of influence relative to 
the object (topic-crossing) and the spatial cut (city regional) in view." (Knieling et al., 2012: 452 trans.)

Yet for all Knieling et al. reveal in terms of the motivations for companies to engage, one aspect not addressed are the actual mechanisms these individual companies use to influence place-based economic development. A missing piece of the jigsaw is the tactics and strategies employed by companies to defend, and enable certain essential interests to be realised. Uncovering the actual mechanisms, that is, the terms of cooperation and how the encounters between the actors involved are structured, enables the determination of what is possible and, crucially, whether a firm (or firms) taking the lead role in place-based economic development offers a genuine alternative to the traditional state-led model. To this end, the remainder of the article examines the tactics and strategies employed by the Peel Group, a private investment group which is taking the lead role in developing an alternative place-based economic development strategy for England's North West region.

\section{PEEL'S ATLANTIC GATEWAY STRATEgy: A NEW FORM OF 'PLACE-BASED' ECONOMIC DEVELOPMENT?}

Launched on 5 September 2008, the Ocean Gateway - later renamed Atlantic Gateway - is a private sector vision and strategy for establishing England's North West region as an internationally significant investment opportunity and to capitalise on its economic potential to be a globally competitive major urban region ${ }^{3}$. Led by the 'Peel Group' (hereafter Peel) the Atlantic Gateway is a region, a concept, an investment strategy, an ambition, and a strategic plan: 
- The Atlantic Gateway region is a 50-kilometre urban corridor connecting the Port of Liverpool in the heart of the Liverpool city-region to the centre of the Greater Manchester city-region along the historic Manchester Ship Canal.

- The Atlantic Gateway concept is a private sector vision for how strategic infrastructural investment can unlock the economic development potential of the area and enable it to become a major driver of national and international economic development and growth.

- The Atlantic Gateway investment strategy centres on Peel’s proposed $£ 50$ billion investment programme in 50 of its most significant projects up to 2050, allied to local public sector support, presenting a compelling co-investment opportunity to UK Government.

- The Atlantic Gateway has the ambition to rebalance the UK in a way that regional policy has failed, ensuring the area is a net contributor to national wealth rather than a net recipient of redistributive state aid.

- The Atlantic Gateway is fast becoming a strategic plan, with its own Partnership Board overseeing its progress and delivery.

Peel's modus operandi is to put forward its ideas for how to drive transformational change and opportunity in the Atlantic Gateway region. In the first 5-years it has evolved and developed the support of others such that it now constitutes a broad, increasingly formalised, public and private sector growth coalition uniting to countenance the Atlantic Gateway concept, deliver the necessary investment, and drive forward the economic regeneration of the Atlantic Gateway area. But the questions are: what motivated Peel to 
take on this leadership role, and crucially, how did the tactics and strategies they employ influence the nature and direction of economic development?

\section{From deliverer to strategic leaders}

Peel's raison d'être is delivering flagship property-led developments. Beginning in the 1970s Peel's modus operandi has traditionally involved acquiring land and property (cheaply, often in former industrial areas where other investors would not consider it to be an investment opportunity), developing it, and generating returns on their investment through rent, public and/or private investment (which pushes up the value of the Peel-owned assets), or onward selling. This business approach has seen Peel deliver two flagship developments in Manchester, the Trafford Centre, a 2 million sq ft retail space, and MediaCityUK, the largest purpose-built media community in Europe in which Peel has so far invested approximately f650 million.

After 25 years of investing in the Atlantic Gateway area, Peel has since taken to engaging in other sectors and across a wider spatial geography. Listed on the London Stock Exchange since 1983, Peel was re-privatised in 2004 as their ambitions saw them quickly expand and develop businesses in other sectors beyond Peel Land \& Property such that the Peel Group now encompasses Peel Advertising, Peel Airports, Peel Energy, Peel Environmental, Peel Leisure, Peel Media, Peel Ports and Peel Waters. Alongside this Peel have acquired significant equity stakes in other major international companies, either through onward selling (such as the 2010 sale of $65 \%$ of Peel Airports to the Vantage Airport Group, owners of 11 airports worldwide, or the sale of the Trafford Centre for a $20 \%$ stake in Intu Properties, owners or part-owners of 16 UK shopping centres with investments valued at $£ 7$ billion) or buying up shares (such as acquiring a $71 \%$ controlling interest in 
Pinewood Shepperton Studios in 2011). It was in the midst of developing this rapidly expanded portfolio of businesses that Peel embarked on Ocean Gateway.

Through Peel's ownership or control of key assets (land, property, infrastructure, utilities) and diffusion into a myriad of economic sectors, Ocean Gateway demonstrates the increasingly dominant influence Peel have over the determinants of economic development in North West England. More significantly, Ocean Gateway unveiled Peel's ambitious longterm plans to capitalise on this dominant influence by moving beyond their trademark of delivering large-scale individual flagship developments to taking the lead in the design and delivery of a major, long-term, co-ordinated cross-sector investment strategy across an area - the Atlantic Gateway - with a 6 million resident population and an economy that contributes in excess of $£ 50$ billion (ca. $6 \%$ ) annually to the UK economy.

The significance of the Atlantic Gateway Strategy becomes most evident when compared to recent state-led place-based economic development initiatives, most notably LEPs. What is striking is that on many of the points LEPs have been criticised (as noted above), the Peel-led Atlantic Gateway appears to represent a genuine alternative placebased economic strategy worthy of consideration. Indicative of this is how: the Atlantic Gateway area is defined by economic priorities, not territorial politics; it has the critical mass to be considered a nationally and internationally significant agglomeration economy; Peel's proposed $£ 50$ billion investment into projects in the Atlantic Gateway by 2050 (including $f 14$ billion of new investment by 2030) suggests it is well-resourced, with flagship schemes involving hundreds of millions - even billions - pounds worth of investment and anticipated returns; and, it is genuinely business-led, by Peel in the first instance and now by the Atlantic Gateway Partnership Board. The magnitude of Atlantic Gateway is not lost on, 
among others, Lord Heseltine, who in an independent report commissioned by the Prime Minister, declared:

"If anywhere in the UK can develop the critical mass and momentum to become an alternative growth pole to London, it is the Atlantic Gateway ... [T]here has never been a credible proposition of that nature in Britain to achieve something decades of regional policy failed to achieve'." (Heseltine and Leahy, 2011: 56-57)

This all points towards the Atlantic Gateway offering a potentially novel approach to placebased economic development, and is one which could stimulate new thinking and provide an alternative framework for realising the socio-economic goals of local and regional development. But it also prompts the need to consider other issues, such as the orientation, merits and dilemmas posed by such an alternative framework. Perhaps most important, the question is: Is it simply replacing one centralised system (state-centralism) with another (Peel-centrism)? To answer this and other related questions it is necessary to examine the tactics and strategies employed by Peel in devising, developing, and delivering Atlantic Gateway.

\section{Tactics and strategies}

When considering the emergence of new, alternative, or novel place-based economic development strategies it is important to ask by whom, for whom, they are being constructed, and why now? In the case of Ocean Gateway these questions are fairly straightforward to answer. John Whitaker, Chairman of Peel, made no secret at the launch 
event of Ocean Gateway that he saw it as a mechanism to both enable, and accelerate, Peel's delivery of major infrastructure, development and regeneration schemes:

“Ocean Gateway should have its own planning regime led by the regional development agency and the local authorities so we can overcome individual local authority objections." (quoted in Barry, 2008: n.p.)

Despite Peel's success in delivering flagship developments, the company remains indignant towards the planning permission process following the long-running battle to secure approval for the Trafford Centre. First proposed in 1986, when Peel acquired the Manchester Ship Canal Company and the land on which the out-of-town shopping centre would eventually be built, it was not until 1995 that the development finally gained approval, after one of the most protracted and expensive planning decisions in UK history. Peel's ambitious plans for large scale co-ordinated investments, involving more complex schemes across a wider geography, raise the stakes in terms of the potential gains but also the potential complexity of securing the necessary planning approvals. Keen to avoid becoming embroiled in similarly long-running planning approval decisions, Ocean Gateway was Peel reaching out - most notably to the Northwest Development Agency (NWDA) which had statutory responsibility for developing and delivering the Regional Economic Strategy (RES) - to secure support for the concept and, by implication, Peel's corporate expansion into different economic sectors and with a wider spatial reach.

Peel's relationship with the NWDA was itself significant prior to the launch of Ocean Gateway, with Peel the developer responsible for delivering a number of the agency's key projects. It was a relationship that grew stronger around the time Ocean Gateway was 
launched, when Robert Hough, Chair of Peel Airports (1997-2009) and Deputy Chair of Peel, first became a Board Member (2007) and then Chair (2009) of the NWDA (while retaining a non-Executive Director role with Peel), with Bryan Grey, the outgoing Chair of NWDA, becoming Chair of Peel Media. This close relationship is significant because Peel saw the NWDA, particularly the statutory responsibility it had for agreeing the RES, as the mechanism to enable their expansionist plans to proceed apace. In effect, the NWDA would become the strategic planning authority to enable Peel to deliver Ocean Gateway. A year before Ocean Gateway was officially launched Peel's relationship with the NWDA was to take on even greater significance when the then Labour government announced it was transferring the statutory responsibility for regional spatial planning to the regional development agencies as part of plans to abolish Regional Assemblies and develop single integrated regional strategies.

The NWDA rebranded Ocean Gateway as Atlantic Gateway, a move that saw the Atlantic Gateway remain close to the original Peel concept of Ocean Gateway but carefully crafted from being a solely Peel initiative to one which included sites and assets located in the area under consideration but not in Peel's ownership (e.g. Daresbury Science Park). Alongside this, the spatial framing changed from Ocean Gateway's singular focus on the idea of an urban growth corridor connecting Liverpool and Manchester to the Atlantic Gateway which is depicted as an amalgamation of two spatial constructs - the Liverpool and Manchester 'city-regions' plus the original Ocean Gateway 'corridor'. This was also to be reflected in the title of the strategy as it changed from Atlantic Gateway - Framework for a Global Growth Opportunity in January 2010 to Atlantic Gateway - Accelerating Growth across the Manchester and Liverpool City Regions: Framework for a Global Growth Opportunity, by February 2010. More than simple semantics, this change reflected non- 
trivial recalibrations to the design of Atlantic Gateway and demonstrated the degree of political manoeuvring Peel had to engage in to secure support for the concept.

The main obstacle Peel faced was the hostile reaction of Manchester City Council. A dispute dating back to Manchester City Council's opposition, first, to Peel's Trafford Centre development (for fear that it would divert investment and revenue away from city-centre retailers), and second, to Peel's partnering with Manchester's neighbouring local authority Salford in a rival - and ultimately successful - bid for MediaCityUk to be located in Salford Quays, the Atlantic (Ocean) Gateway proposals re-ignited this latent tension between Peel and Manchester City Council. The city council saw Atlantic (Ocean) Gateway as diverting attention away from their city-region, in particular Peel's plans to exploit housing and employment land opportunities in the corridor between the Liverpool and Manchester cityregions (Manchester City Council, 2010a, 2010b). Using the NWDA to broker support for the concept, the plans for housing sites was removed and the emphasis put on Peel's Ocean Gateway spatial concept prioritising growth along the corridor was downgraded such that it was presented as supporting, rather than rivalling, growth in the city-region.

Still intrinsically Peel's original concept, Atlantic Gateway was officially launched by the NWDA in March 2010, five months before the first North West Integrated Regional Strategy (RS2010) was published. The timing is significant because at the time of the launch, the NWDA were consulting on the key spatial priorities for RS2010. When RS2010 was published Peel's strategy had paid dividends - they had secured statutory support for the Atlantic Gateway since the NWDA listed Manchester city-region, Liverpool city-region, and the Atlantic Gateway as the key 'priorities for places' from a North West regional perspective (NWDA, 2010a). Nevertheless, Peel failed to secure the NWDA becoming planning authority for Atlantic Gateway because no sooner had the scheme been recognised 
in RS2010 than the newly formed Conservative-Liberal Democrat coalition government announced the abolition of Regional Development Agencies and the creation of LEPs.

If the LEP process appeared abstract and of no immediate consequence to other businesses, this was certainly not true for Peel. Invited to submit outline proposals, setting out how they would work with government to strengthen local economies, the Coalition Government gave local authority leaders and business leaders just 69 days to design the new institutional architecture for a new era of subnational economic development in England. In the Atlantic Gateway area, while the three subregional areas - Manchester cityregion, Liverpool city-region, and Cheshire \& Warrington - each submitted their outline proposals, Peel had been working on developing their own proposal for an Atlantic Gateway LEP. Badged as a "private sector-led special purpose LEP" which could "complement the other LEPs" (Peel, 2010: ii) Peel's new strategy was to secure backing for their investment plans directly from central government.

This new tactic was forced upon Peel; having lost their main ally their political bargaining power was weakened. Nonetheless, Peel's response to the LEP proposals did avail them some negotiating power in the North West. Initially courting controversy for not engaging local authorities in their plans, a Regional Leaders Forum was convened for 7 September 2010 (the day after the Government deadline for outline LEP proposals to be submitted) to discuss Peel's proposal. Without direct support from local authorities, Peel withdrew its LEP bid, following representation at the meeting by regional stakeholders including the local authorities. Instead, it was agreed that an inclusive, partnership-based Atlantic Gateway Board - including one local authority representative from each LEP would be established to secure strategic alignment with the 3 LEPs, to deliver the strongest level of partnership buy-in, and to develop and deliver Atlantic Gateway. A much less 
powerful resolution than Peel were initially pursuing, that they were still able to advance the Atlantic Gateway in the right strategic direction post-RDAs is testament to the inherent political power their land holdings and ownership of assets affords them in the North West.

If the transition from RDAs to LEPs saw Atlantic Gateway lose some of its impetus regionally, the change in national government presented a series of counter opportunities to advance apace the development of Atlantic Gateway. First, the formation of Conservative-led coalition government allied to programmes of fiscal austerity had led to wide-ranging cuts in the public sector and greater emphasis placed on business leading on the delivery of jobs, growth and regeneration, as well as on the provision of services previously delivered by the state. Second, the model of economic growth pursued by the Cameron-led government aspires to reduce the deficit and rebalance the economy (both geographically and by sector). Third, reform of the public bodies landscape - such as the removal of RDAs - is designed, in part, to enable a better dialogue between business and government and to facilitate greater business-engagement in informing public policy and shaping policy interventions (Cabinet Office, 2010). And fourth, responding to pressure from business groups and international organisations, notably the IMF, to bring infrastructure investments forward to offset planned austerity and to act as an immediate stimulus for economic growth, the UK Government has increased investment in infrastructure and more broadly infrastructure-led economic regeneration.

It can be argued that Atlantic Gateway is a proposition likely, therefore, to gain more favour in the corridors of Westminster and Whitehall. Indeed, and this is critical, because Atlantic Gateway's success relies on co-investment, particularly from HM Government, because for all Peel's landholdings, assets and sector involvement, the connecting infrastructure (e.g. road, rail links) that is so central to unlocking the growth potential in the 
Atlantic Gateway area remain beyond the direct control of Peel or the other public-private partners. It can be seen that the current tactic and strategy being employed is to gain public sector investment in infrastructure to complement the Atlantic Gateway development, and it is one that is arguably producing some dividends ${ }^{4}$.

\section{CONCLUSION: IS THERE A ROLE FOR NON-STATE 'PLACE-BASED' ECONOMIC DEVELOPMENT STRATEGY?}

According to Fabrizio Barca, author of the highly influential report for the European Commission on the reform of EU cohesion policy, "the 'place-based' approach is the 'new paradigm' of regional policy" (Barca, 2009: xi; see also OECD, 2009). Yet as this article has sought to reveal, it may be a very different type of place-based approach that determines local and regional development in the future. It can be argued that although the Atlantic Gateway might be somewhat unique (owing to the spatial proximity of Peel's landholdings and assets), the processes underpinning it are arguably not unique to Peel and North West England. This is being recognised by those internal to the Atlantic Gateway, such as Steven Broomhead (former NWDA Chief Executive and current advisor to the Atlantic Gateway Partnership Board):

"We all know the public purse is going to be constrained - it will be private investment which will characterise the next decade." (NWDA, 2010b: 1)

It is also recognised by those external to the Atlantic Gateway:

"Fundamentally, the era of predominantly public finance investment in infrastructure is over and thus regeneration programmes will have to adapt to this new environment." (Howell, 2012: 5) 
The argument being put forward in this article is that the rise of the non-state spatial strategy may well become the norm and a potentially soon to be dominant feature of placebased economic development. Here in this article, the Atlantic Gateway, an entirely privatesector led strategic development initiative, is presented as a looking glass onto this potentially new, alternative and novel approach to the design, development and delivery of place-based economic development strategies. In addition to this, two points are worthy of particular emphasis.

First, by focusing on the business involved as opposed to business involvement per se, it has been demonstrated that while Peel's motivation for engaging in the design and development of a place-based economic development strategy has remained largely unchanged over time, the tactics and strategies required to defend, enable certain essential interests to be realised have had to evolve. Alongside this, Peel's capacity to "bargain out" (Stone, 1989) and renegotiate the terms of cooperation so that the strategic priorities of other local, regional and national groups become increasingly aligned to their corporate interests serves to draw particular attention to ideas of power in the practice of economic development. On this, it is particularly interesting to consider the view of Susan Williams, Executive Director of Atlantic Gateway:

“We don't have power as such because we are not a bureaucratic organ. But we do have the ability to change the whole of the North West - our power lies in investment, the way we get people working together, the power in getting things done." (quoted in Morgan, 2012: 6) 
Atlantic Gateway and other private-sector led initiatives of this type may not have pure power but they do have the "power to" (Stone, 1989) influence, align and shape the future direction of economic development, particularly at the local and regional level. Democratic institutions do still retain power to decide what type of place-based economic development is legitimated and for whose benefit, but the question this article raises is for how long this can be sustained when private investment is becoming the only way economic development and regeneration can take place and local accountability structures are being undermined by austerity and longstanding failures to successfully devolve political power in England.

The second and related point appertains to the status of place-based economic development strategies in England - specifically LEPs. In their recent edited collection, Where next for Local Enterprise Partnerships? Ward and Hardy (2013: 9) are led to conclude that "we need LEPs with larger areas, proper funding for running costs, experienced staff, and access to capital". Perhaps in looking at Atlantic Gateway, and other potential privatesector led initiatives of this type, it can be seen that they represent many of things a LEP should be ... and in the case of Atlantic Gateway, the LEP that never was. 


\section{ACKNOWLEDGEMENTS}

Earlier versions of this article were presented at a number of conferences and research seminars. The author wishes to thank the audience at these events, Emma Clarence and the two anonymous referees for their constructive comments on earlier versions of this article. The usual disclaimers apply.

\section{FUNDING}

This work was supported by the Regional Studies Association [Early Career Grant].

\section{Endnotes}

1. It goes without saying that businesses believe they should play a significant role in economic development; indeed the need for business involvement in economic development has over recent decades become a hegemonic discourse within public policy-making circles.

2. There is not the space to go into these in detail other than to say firm-centred analyses clearly raise the potential for researcher issues for dealing with corporate confidentiality, the nature of private firm information (e.g. access and dissemination of information about motivations, situations, business planning and so on), and potential conflicts of interest between researcher and private firm.

3. This section draws on empirical research conducted by the author during 2013. This took the form of both desktop research and semi-structured interviews (25) with inter alia Atlantic Gateway board members (both public and private), local authority officials, government departments, businesses and business representatives.

4. There is some evidence to support this - for example, the Cameron-led government has established a cluster of 3 enterprise zones in the Atlantic Gateway area (the largest of which is a Peel site), confirmed the $f 560 m$ Northern Hub rail improvement scheme will be funded in full, approved Peel's $f 5.5 \mathrm{bn}$ Liverpool Waters regeneration schemes despite strong calls for a public inquiry, and provided a $£ 35 \mathrm{~m}$ grant to enable work on 
Peel Ports new $£ 300 \mathrm{~m}$ Liverpool 2 container terminal to begin - but how much of this can be attributed directly to Atlantic Gateway remains contested. 


\section{REFERENCES}

Barca F (2009) An Agenda for a Reformed Cohesion Policy. A Place-based Approach to Meeting European Union Challenges and Expectations. Brussels: DG Regio, European Commission.

Barry C (2008) Planning supremo seeks planning revolution. Manchester Evening News Business [Online], 8 September.

Bentley G and Pugalis L (2013) LEPs - forming, storming, norming, performing, adjourning. In: Ward M and Hardy S (eds) Where Next for Local Enterprise Partnerships? London: RSA/Smith Institute, pp. 36-45.

Cabinet Office (2010) Public Bodies Reform - Proposals for Change. London: HM Government.

Cominetti N, Crowley L and Lee N (2012) The Business of Cities - The Private Sector, Local Enterprise Partnerships and Growth. London: The Work Foundation.

Cox K and Mair A (1989) Urban growth machines and the politics of local economic development. International Journal of Urban and Regional Research 13(1): 137-146.

Gash T, Randall J and Sims S (2014) Achieving Political Decentralisation - Lessons from 30 years of attempting to devolve political power in the UK. London: Institute for Government.

Harrison J (2008) Stating the production of scales: centrally orchestrated regionalism, regionally orchestrated centralism. International Journal of Urban and Regional Research 32(4): 922-941.

Harrison J (2012) Life after regions? The evolution of city-regionalism in England. Regional Studies 46(9): 1243-1259. 
Harrison J (2013) Reconfiguring city-regionalism as the production of new non-state spatial strategies: the case of Peel Holdings Atlantic Gateway Strategy. Urban Studies DOI: 10.1177/0042098013493481.

Heseltine M and Leahy T (2011) Rebalancing Britain: Policy or Slogan? Liverpool City Region - Building on its Strengths: An Independent Report/ London: Department for Business, Innovation and Skills.

House of Commons Business, Innovation and Skills Select Committee (2013) Lord Heseltine's Report: No Stone Unturned in Pursuit of Growth - Oral Evidence, HC 823-i and -ii. London: The Stationery Office.

Howell S (2012) Grow Your Own Way: Taking a Localist Approach to Regeneration. London: LGA/Localis.

Jackson M, McInroy N and Nolan A (2013) LEPs and local government - forging a new era of progressive economic development? In: Ward M and Hardy S (eds) Where Next for Local Enterprise Partnerships. London: RSA/Smith Institute, pp. 25-35.

Jones M (2013) 'It's like deja vu, all over again'. In: Ward M and Hardy S (eds) Where Next for Local Enterprise Partnerships. London: RSA/Smith Institute, pp. 86-95.

Knieling J, Othengrafen $F$ and Preising $T$ (2012) Privatisierung von stadt-und regionalentwicklung: gesellschaftlicher nutzen oder verwirklichung von unternehmenszielen? "Corporate spatial responsibility" oder "corporate spatial strategy "? [trans. Privatization of urban and regional development: achieving social benefits or business objectives? 'Corporate spatial responsibility' or 'corporate spatial strategy'?] Raumforschung und Raumordnung 70(5): 451-464. 
Manchester City Council (2010a) Report for Resolution: Manchester City Council Consultation Response: Atlantic Gateway - Framework for a Global Growth Opportunity. 10 March.

Manchester City Council (2010b) Report for Resolution: Greater Manchester Local Enterprise Partnership and Regional Transition Planning. 15 September.

Morgan P (2012) People are now thinking much more creatively about how we can get things done - together. The Times - Business Insight 29 November, p. 6.

NWDA (2010a) Future North West: Our Shared Priorities. Warrington: NWDA.

NWDA (2010b) Press release - Atlantic Gateway Strategy launched. Warrington: NWDA.

OECD (2009) How Regions Grow Trends and Analysis. Paris: OECD.

Peck J (1995) Moving and shaking: business elites, state localism and urban privatism. Progress in Human Geography 19(1): 16-46.

Peel (2010) A response by the private sector to the Government's request for outline proposals in relation to Local Enterprise Partnerships (LEPS) in respect of Atlantic Gateway. Manchester: Peel Group.

Pugalis L and Bentley $G$ (this issue) (Re)appraising place-based economic development strategies. Local Economy XXX

Rodríguez-Pose A and Gill N (2003) The global trend towards devolution and its implications. Environment and Planning C 21(3): 333-351.

SQW (2010) Local Enterprise Partnerships - A New Era Begins? Cambridge: SQW.

Stone C (1989) Regime Politics: Governing Atlanta, 1946-1988. Lawrence: University of Kansas Press.

Syrett S and Bertotti M (2012) Reconsidering private sector engagement in subnational economic governance. Environment and Planning A 44(10): 2310-2326. 
Walker D (2012) Regionalism: a thoroughly wicked issue. Guardian Professional 5 March.

Ward M and Hardy S (2013) Where next for Local Enterprise Partnerships? London: The Smith Institute/Regional Studies Association.

Wood A (2004) Domesticating urban theory? US concepts, British cities and the limits of crossnational applications. Urban Studies 41(11): 2103-2118 